\title{
Effect of Integrated Nutrient Management on Growth, Yield and quality of Okra (Abelmoschus esculentus (L.) Moench)
}

\author{
Bipul Kumar Singh ${ }^{1 *}$, R.B. Verma ${ }^{1}$, V.K. Singh ${ }^{1}$, Mahendra Singh ${ }^{2}$ and \\ Deepak Maurya ${ }^{1}$ \\ ${ }^{1}$ Department of Horticulture (Vegetable and Floriculture), ${ }^{2}$ Department of Soil Science and \\ Agricultural Chemistry, Bihar Agricultural University, Bhagalpur, Bihar-813 210, India \\ *Corresponding author
}

A B S T R A C T

\begin{tabular}{|l|}
\hline K e y w or d s \\
$\begin{array}{l}\text { Integrated, Bio- } \\
\text { inoculants, Inorganic, } \\
\text { Vermicompost, Yield }\end{array}$ \\
\hline Article Info \\
\hline $\begin{array}{l}\text { Accepted: } \\
\text { 10 September } 2018 \\
\text { Available Online: } \\
10 \text { October } 2018\end{array}$ \\
\hline
\end{tabular}

A field experiment was carried out at Vegetable Research Farm, Department of Horticulture (Vegetable and Floriculture), Bihar Agricultural University, Sabour during Kharif season of 2017 to study the integrated effect of bio-inoculants, organic and chemical fertilizers on growth, yield and economics of okra. The sixteen integrated treatments consisting chemical, organic and biofertilizers were arranged in a randomized block design replicated thrice. Results revealed that the application of $75 \%$ RDN through chemical fertilizer $+25 \% \mathrm{~N}$ through vermicompost + Azotobacter@ $20 \mathrm{~g} \mathrm{~kg}^{-1}$ of seed+ PSB @ $20 \mathrm{~g} \mathrm{~kg}^{-1}$ of seed $\left(\mathrm{T}_{14}\right)$ influenced most of the characteristics significantly and recorded the highest values of plant height, number of branches per plant, fruit length, average fruit weight, number of fruits per plant, yield per hectare and B: C ratio (1.62) except number of nodes to first flower appearance, days taken to $50 \%$ flowering and days to first picking, which were the minimum under same treatment $\left(T_{14}\right)$. The quality parameters viz. the ascorbic acid, TSS and crude protein content in fruit were also highest in $\mathrm{T}_{14}$ treatment. Thus it can be inferred that $25 \%$ of RDN can only be substituted through Vermicompost along with the use of biofertilizers (Azotobacter + PSB)

\section{Introduction}

The cultivated okra [Abelmoschus esculentus (L.) Moench] is an important fruit vegetable crop cultivated in tropical, subtropical and mild temperate parts of the world and belongs to the family Malvaceae In India, it is grown during summer and rainy seasons for its tender pod, which are cooked and consumed as a vegetable (Chattopadhyay et al., 2011). The fibres of mature fruits and stem are used in the paper industry, while the ripe seeds (roasted and ground) are used as substitute of coffee in Africa. Theroots and stems are used for cleaning the cane juice from which gur or brown sugar is prepared (Chauhan, 1972).

The demand of the crop is significantly increasing with the increase in population, which emphasises the use of chemical 
fertilizers; as a result growers indiscriminately use the inorganic sources of plant nutrients, which posed the serious threat to the soil health, environment and on the health of millions of people throughout the world and more importantly declining the productivity of soil. Vermicompost is a good source of micro and macro nutrients and acts as chelating agent in regulating the availability of metabolic nutrients to the plants and increases the plant growth and yield by providing nutrients in available form. Recently, the biofertilizers fix atmospheric nitrogen, solubilize and mobilize phosphorus; translocate minor elements like zinc, copper etc, to the plants, produce plant growth promoting hormones, vitamins and amino acids and used as alternative to the part of chemical fertilizers due to cost effective and renewable source of plant nutrients. Sustainable increase in production is possible by adopting integrated fertilizer management, which notonly increase the nutrient status of soil but also help to improve various physical, chemical and biological properties of soil leading to improved soil fertility and also to increase fertilizer use efficiency (Dick and Greegorich, 2009). Keeping all the facts in view, the present investigation was planned to explore the economically feasible integrated nutrient management (INM) option for the better growth, yield and quality of okra.

\section{Materials and Methods}

The experiment was carried out at Vegetable Research Farm, Department of Horticulture (Vegetable and Floriculture), Bihar Agricultural University, Sabour, Bhagalpur during Kharif season of 2017. Bhagalpur is situated between $25^{\circ} 50^{\prime} \mathrm{N}$ latitude and $87^{\circ} 19^{\prime}$ E longitudes with an altitude of 52.73 meters above sea level. Sixteen INM treatments i.e. $\mathrm{T}_{1}$ - Recommended dose of fertilizers (RDF), $\mathrm{T}_{2}-(75 \%$ of RDN through chemical fertilizer + $25 \%$ RDN through Vermicompost), $\mathrm{T}_{3}-(50 \%$ of RDN through chemical fertilizer $+50 \%$ RDN through Vermicompost), $\mathrm{T}_{4}-(25 \%$ of RDN through chemical fertilizer $+75 \%$ RDN through Vermicompost), $\mathrm{T}_{5}-\left(\mathrm{T}_{1}+\right.$ Azotobacter $), \mathrm{T}_{6}-\left(\mathrm{T}_{2}+\right.$ Azotobacter $), \mathrm{T}_{7}-\left(\mathrm{T}_{3}+\right.$ Azotobacter $), \mathrm{T}_{8}-\left(\mathrm{T}_{4}+\right.$ Azotobacter $), \mathrm{T}_{9-}\left(\mathrm{T}_{1}\right.$ $+\mathrm{PSB}), \mathrm{T}_{10}-\left(\mathrm{T}_{2}+\mathrm{PSB}\right), \mathrm{T}_{11^{-}}\left(\mathrm{T}_{3}+\mathrm{PSB}\right), \mathrm{T}_{12-}$ $\left(\mathrm{T}_{4}+\mathrm{PSB}\right), \mathrm{T}_{13}-\left(\mathrm{T}_{1}+\mathrm{PSB}+\right.$ Azotobacter $)$, $\mathrm{T}_{14}-\left(\mathrm{T}_{2}+\mathrm{PSB}+\right.$ Azotobacter $), \mathrm{T}_{15}-\left(\mathrm{T}_{3}+\mathrm{PSB}\right.$ + Azotobacter $)$ and $\mathrm{T}_{16}-\left(\mathrm{T}_{4}+\mathrm{PSB}+\right.$ Azotobacter) were arranged in a Randomized Block Design replicated thrice. The field was thoroughly prepared and experimental plots of $3.0 \mathrm{~m} \times 2.25 \mathrm{~m}$ size were made. Vermicompost was applied as per the treatment after layout of experiment. One third of nitrogen and full dose of phosphorus and potassium in the form of urea, diammonium phosphate (DAP) and muriate of potash (MOP) were applied at the time of sowing. Two seeds per hill were sown at a spacing of $50 \times 45 \mathrm{~cm}$ during the month of July, 2017. Remaining two third of nitrogen in the form of urea was applied in two equal split doses at 30 and 60 days after sowing (DAS). The treated seeds with Azotobacter and PSB inoculants as per the treatment were used for sowing. For this $125 \mathrm{~g}$ of Jaggery was mixed in one litre of boiled water, 200gof Azotobacter and PSB culture was poured in Jaggery solution separately and stirred well. The inoculated seeds were sown on the same day after air dry in shade. All other cultural and plant protection measures were done as per the recommended package of practices for the healthy crop. The observations were recorded on growth characters (Plant height, Number of branches per plant, Number of nodes at which first flower appear), Flowering characters (Number of days required for $50 \%$ flowering, Days taken to first picking), yield and yield attributing traits (Number of fruits per plant, Fruit length $(\mathrm{cm})$, Fruit diameter $(\mathrm{mm})$, Average fruit weight $(\mathrm{g})$, yield of fruits per plant $(\mathrm{g})$ and total yield $(\mathrm{q} / \mathrm{ha})$. Quality parameters like TSS, Ascorbic acid and Crude Protein contents in fruits were measured using 
a manual hand refractometer, volumetric method and Micro - Kjeldahl method as suggested by Vishnyakov et al., (2005), AOAC (2001) and Motsara and Roy (2008), respectively. The data were collected and subjected to statistically analysis using analysis of variance (ANOVA) under Randomized Block Design as described by Panse and Sukhatme (1985). The critical difference was also calculated to draw the valid conclusion.

\section{Results and Discussion}

\section{Morphological and phenological traits}

Data presented in Table 1showed that the plant height $(90.40,118.33 \mathrm{~cm})$ and number of branches / plant $(3.30,5.10)$ at 60 and 90 days, respectively increased significantly with the application of $75 \%$ RDN through chemical fertilizer $+25 \%$ RDN through vermicompost + Azotobacter + PSB $\left(\mathrm{T}_{14}\right)$ while, the minimum plant height and number of branches per plant was observed in $\mathrm{T}_{4}(25 \% \mathrm{RDN}$ through chemical fertilizer $+75 \%$ RDN through vermicompost).

Application of nutrient in integration of bioinoculant, vermicompost and chemical fertilizers might have created favourable conditions for proper growth and development of plants. The better efficiency of organic manures is due to the fact that they might have provided both macro and micro nutrients at their optimal levels which ultimately enhanced the early growth phases and encouraged reproductive growth as well. Application of biofertilizers has ability to supply the plant promoting substances (Indole Acetic acid, Gibberellic acid and Cytokinins like substances) to the plants, which stimulated plant growth traits, absorption and metabolism (Lambert et al., 1979).Similar observations have also been made by Sharma and Choudhary (2011) and Das et al., (2014).
Various treatments of INM brought significant variation for all the phenotypic characters studied. The minimum nodes to first flowering (5.20 nodes), days taken to $50 \%$ flowering (41.53 days) and days taken to first fruit picking (47.23) were observed under the treatment receiving $75 \%$ RDN through chemical fertilizer $+25 \%$ RDN through vermicompost + Azotobacter $+\mathrm{PSB}\left(\mathrm{T}_{14}\right)$ while, maximum nodes to first flowering (7.10), days to $50 \%$ flowering (48.42 days) and first fruit picking (54.90) were recorded under the treatment $\mathrm{T}_{4}(25 \% \mathrm{RDN}$ through chemical fertilizer $+75 \%$ RDN through vermicompost). The reduced trends in the parameters due to higher doses of RDN through chemical fertilisers may be attributed to favourable effect of vermicompost, Azotobacter and PSB on microbial activity and root proliferation in soil, which caused solubilizing effect on native nitrogen, phosphorus, potassium and other macro and micro nutrients. The reduced dose of chemical fertilizers supplemented with organic manures also decreased exploitation of micronutrients.

Integration of organic and inorganic fertilizers favoured vigorous growth and synthesized more cytokinins in plants, which might have helped to the translocation of cytokinins as well as more quantity of available phosphorus through the xylem vessels and their accumulation in the axillary buds that would have favoured the plant to enter into reproductive phase (Dange et al., 2002). Similar results have also been reported by Singh et al., (2012) and Sharma et al., (2014).

\section{Yield components and yield}

The integrated use of organic, inorganic and bio-inoculants could bring significant differences on yield attributing characters viz., fruit length, fruit diameter, fruit weight, number of fruit per plant and yield per plant (Table 2 and Fig. 1). 
Table.1 Effect of various treatments on morphological and phenological traits of okra

\begin{tabular}{|c|c|c|c|c|c|c|c|}
\hline \multirow[t]{2}{*}{ Symbol } & \multicolumn{2}{|c|}{ Plant height } & \multicolumn{2}{|c|}{$\begin{array}{l}\text { Number of } \\
\text { branches }\end{array}$} & \multirow[t]{2}{*}{$\begin{array}{l}\text { Nodes } \\
\text { to first } \\
\text { flower }\end{array}$} & \multirow[t]{2}{*}{$\begin{array}{c}\text { Days to } 50 \\
\% \\
\text { flowering }\end{array}$} & \multirow[t]{2}{*}{$\begin{array}{l}\text { Days to } 1^{\text {st }} \\
\text { fruit } \\
\text { picking }\end{array}$} \\
\hline & 60 DAS & 90 DAS & 60 DAS & 90 DAS & & & \\
\hline$\overline{T_{1}}$ & 73.30 & 100.33 & 2.27 & 3.53 & 7.03 & 47.13 & 54.13 \\
\hline$\overline{T_{2}}$ & 75.53 & 103.27 & 2.67 & 3.72 & 6.80 & 46.07 & 52.47 \\
\hline$T_{3}$ & 75.4 & 102.0 & 2.62 & 3.67 & 6.80 & 46.47 & 52.60 \\
\hline$\overline{T_{4}}$ & 71.40 & 94.42 & 2.15 & 3.13 & 7.10 & 48.42 & 54.90 \\
\hline $\mathbf{T}_{5}$ & 76.83 & 105.33 & 2.47 & 3.93 & 6.70 & 46.37 & 53.10 \\
\hline$\overline{T_{6}}$ & 79.63 & 108.27 & 2.67 & 4.22 & 6.63 & 44.93 & 51.33 \\
\hline$T_{7}$ & 79.10 & 107.00 & 2.58 & 4.18 & 6.57 & 45.07 & 51.63 \\
\hline$\overline{T_{8}}$ & 75.13 & 100.57 & 2.20 & 3.26 & 6.90 & 47.37 & 53.50 \\
\hline$T_{9}$ & 76.27 & 104.33 & 2.42 & 3.66 & 6.40 & 46.67 & 53.13 \\
\hline $\mathbf{T}_{10}$ & 79.07 & 107.17 & 2.67 & 3.97 & 6.33 & 45.10 & 51.40 \\
\hline $\mathbf{T}_{11}$ & 78.63 & 105.00 & 2.55 & 3.93 & 6.27 & 45.27 & 51.87 \\
\hline$T_{12}$ & 74.70 & 100.17 & 2.15 & 3.35 & 6.63 & 47.63 & 53.77 \\
\hline$\overline{T_{13}}$ & 86.53 & 115.00 & 2.62 & 4.07 & 5.40 & 43.33 & 49.80 \\
\hline $\mathbf{T}_{14}$ & 90.40 & 118.33 & 3.30 & 5.10 & 5.20 & 41.53 & 47.23 \\
\hline $\mathbf{T}_{15}$ & 88.77 & 117.33 & 3.20 & 5.03 & 5.23 & 42.27 & 47.77 \\
\hline$T_{16}$ & 82.37 & 108.00 & 2.39 & 3.80 & 5.90 & 43.60 & 50.72 \\
\hline SEm \pm & 2.62 & 3.06 & 0.17 & 0.20 & 0.30 & 1.16 & 1.21 \\
\hline CD at $5 \%$ & 7.58 & 8.85 & 0.50 & 0.56 & 0.88 & 3.34 & 3.49 \\
\hline
\end{tabular}

$\mathrm{T}_{1}=$ Recommended dose of fertilizers $(\mathrm{RDF}), \mathrm{T}_{2}=(75 \%$ of RDN through chemical fertilizer $+25 \%$ RDN through Vermicompost), $\mathrm{T}_{3}=(50 \%$ of RDN through chemical fertilizer $+50 \%$ RDN through Vermicompost $), \mathrm{T}_{4}=(25 \%$ of RDN through chemical fertilizer $+75 \%$ RDN through Vermicompost $), \mathrm{T}_{5}=\left(\mathrm{T}_{1}+\right.$ Azotobacter $), \mathrm{T}_{6}=\left(\mathrm{T}_{2}+\right.$ Azotobacter $), \mathrm{T}_{7}=\left(\mathrm{T}_{3}+\right.$ Azotobacter $), \mathrm{T}_{8}=\left(\mathrm{T}_{4}+\right.$ Azotobacter $), \mathrm{T}_{9}=\left(\mathrm{T}_{1}+\mathrm{PSB}\right), \mathrm{T}_{10}=\left(\mathrm{T}_{2}+\mathrm{PSB}\right), \mathrm{T}_{11}=\left(\mathrm{T}_{3}+\mathrm{PSB}\right)$, $\mathrm{T}_{12}=\left(\mathrm{T}_{4}+\mathrm{PSB}\right), \mathrm{T}_{13}=\left(\mathrm{T}_{1}+\mathrm{PSB}+\right.$ Azotobacter $), \mathrm{T}_{14}=\left(\mathrm{T}_{2}+\mathrm{PSB}+\right.$ Azotobacter $), \mathrm{T}_{15}=\left(\mathrm{T}_{3}+\mathrm{PSB}+\right.$ Azotobacter $)$ and $\mathrm{T}_{16}=\left(\mathrm{T}_{4}+\mathrm{PSB}+\right.$ Azotobacter $)$ 
Table.2 Effect of integrated nutrient management on yield and yield attributing characters and quality of okra

\begin{tabular}{|c|c|c|c|c|c|c|c|c|c|}
\hline & \multicolumn{6}{|c|}{ Yield and yield attributing characters } & \multicolumn{3}{|l|}{ Quality } \\
\hline Symbol & $\begin{array}{l}\text { Fruit } \\
\text { length } \\
(\mathrm{cm})\end{array}$ & $\begin{array}{c}\text { Fruit } \\
\text { diameter } \\
(\mathbf{m m})\end{array}$ & $\begin{array}{l}\text { Average } \\
\text { fruit } \\
\text { weight (g) }\end{array}$ & $\begin{array}{c}\text { Number } \\
\text { of fruits } \\
\text { per plant }\end{array}$ & $\begin{array}{c}\text { Fruits } \\
\text { yield } \\
\text { (g/plant) }\end{array}$ & $\begin{array}{l}\text { Fruit } \\
\text { yield } \\
\text { (q/ha) }\end{array}$ & $\begin{array}{c}\text { TSS } \\
\left({ }^{0} \mathrm{Brix}\right)\end{array}$ & $\begin{array}{l}\text { Ascorbic acid } \\
\text { in fruits } \\
\text { (mg/100 g) }\end{array}$ & $\begin{array}{c}\text { Crude } \\
\text { protein } \\
(\%)\end{array}$ \\
\hline$T_{1}$ & 12.18 & 12.80 & 12.50 & 20.50 & 248.70 & 106.83 & 1.97 & 13.55 & 14.20 \\
\hline$\overline{T_{2}}$ & 13.03 & 13.93 & 12.73 & 21.07 & 267.46 & 114.19 & 2.02 & 14.13 & 14.93 \\
\hline $\mathbf{T}_{3}$ & 12.97 & 13.87 & 12.63 & 21.03 & 262.33 & 113.65 & 1.99 & 14.03 & 14.80 \\
\hline $\mathbf{T}_{4}$ & 11.93 & 12.50 & 12.00 & 20.03 & 239.54 & 101.75 & 1.98 & 13.67 & 14.57 \\
\hline$\overline{T_{5}}$ & 12.52 & 13.73 & 12.60 & 22.07 & 277.25 & 112.40 & 2.03 & 14.00 & 15.00 \\
\hline $\mathrm{T}_{6}$ & 14.03 & 14.42 & 13.00 & 22.93 & 297.43 & 125.59 & 2.18 & 14.63 & 15.63 \\
\hline$T_{7}$ & 13.97 & 14.33 & 12.93 & 22.87 & 294.99 & 125.52 & 2.17 & 14.53 & 15.53 \\
\hline $\mathrm{T}_{8}$ & 12.43 & 13.28 & 12.13 & 22.00 & 267.21 & 109.65 & 2.07 & 14.23 & 15.23 \\
\hline $\mathrm{T}_{9}$ & 12.50 & 13.57 & 12.55 & 22.00 & 275.65 & 112.03 & 2.01 & 13.97 & 14.97 \\
\hline$T_{10}$ & 14.00 & 14.37 & 12.97 & 22.87 & 296.22 & 125.03 & 2.15 & 14.60 & 15.60 \\
\hline$T_{11}$ & 13.83 & 14.27 & 12.77 & 22.83 & 291.27 & 124.90 & 2.14 & 14.50 & 15.50 \\
\hline$T_{12}$ & 12.40 & 13.17 & 12.07 & 21.97 & 265.25 & 108.87 & 2.04 & 14.17 & 15.17 \\
\hline$T_{13}$ & 13.60 & 14.40 & 13.17 & 22.60 & 298.26 & 114.08 & 2.14 & 14.53 & 15.73 \\
\hline$T_{14}$ & 15.47 & 16.20 & 14.10 & 24.83 & 349.48 & 137.60 & 2.42 & 15.37 & 16.63 \\
\hline$T_{15}$ & 14.90 & 15.97 & 13.90 & 24.53 & 340.32 & 135.42 & 2.30 & 15.07 & 16.27 \\
\hline$T_{16}$ & 13.47 & 14.23 & 13.00 & 22.53 & 292.73 & 113.92 & 2.17 & 14.60 & 15.80 \\
\hline SEm \pm & 0.41 & 0.56 & 0.30 & 0.54 & 10.81 & 3.39 & 0.06 & 0.26 & 0.27 \\
\hline CD at $5 \%$ & 1.17 & 1.63 & 0.86 & 1.57 & 31.22 & 9.80 & 0.16 & 0.74 & 0.77 \\
\hline
\end{tabular}

$\mathrm{T}_{1}=\mathrm{RDF}, \mathrm{T}_{2}=(75 \%$ of RDN through chemical fertilizer $+25 \% \mathrm{RDN}$ through Vermicompost $), \mathrm{T}_{3}=(50 \%$ of RDN through chemical fertilizer $+50 \%$ RDN through Vermicompost $), \mathrm{T}_{4}=(25 \%$ of RDN through chemical fertilizer + 75\% RDN through Vermicompost $), \mathrm{T}_{5}=\left(\mathrm{T}_{1}+\right.$ Azotobacter $), \mathrm{T}_{6}=\left(\mathrm{T}_{2}+\right.$ Azotobacter $), \mathrm{T}_{7}=\left(\mathrm{T}_{3}+\right.$ Azotobacter $), \mathrm{T}_{8}=$ $\left(\mathrm{T}_{4}+\right.$ Azotobacter $), \mathrm{T}_{9}=\left(\mathrm{T}_{1}+\mathrm{PSB}\right), \mathrm{T}_{10}=\left(\mathrm{T}_{2}+\mathrm{PSB}\right), \mathrm{T}_{11}=\left(\mathrm{T}_{3}+\mathrm{PSB}\right), \mathrm{T}_{12}=\left(\mathrm{T}_{4}+\mathrm{PSB}\right), \mathrm{T}_{13}=\left(\mathrm{T}_{1}+\mathrm{PSB}+\right.$ Azotobacter $), \mathrm{T}_{14}=\left(\mathrm{T}_{2}+\mathrm{PSB}+\right.$ Azotobacter $), \mathrm{T}_{15}=\left(\mathrm{T}_{3}+\mathrm{PSB}+\right.$ Azotobacter $)$ and $\mathrm{T}_{16}=\left(\mathrm{T}_{4}+\mathrm{PSB}+\right.$ Azotobacter $)$

Table.3 Economic feasibility of various INM treatments in okra

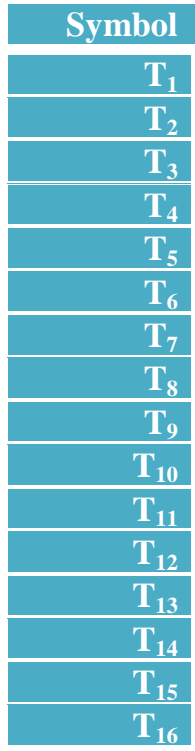

\begin{tabular}{|r|}
\hline Cost of cultivation $\left(\mathrm{Rs} \mathrm{ha}^{-1}\right)$ \\
43910.00 \\
52515.80 \\
61125.20 \\
69734.40 \\
43925.00 \\
52530.80 \\
61140.20 \\
69749.40 \\
43925.00 \\
52530.80 \\
61140.20 \\
69749.40 \\
43940.00 \\
52545.80 \\
61155.20 \\
69764.40 \\
\hline
\end{tabular}

\section{Gross income}

106833.33

114193.33

113650.00

101746.67

112400.00

125590.00

125516.67

109653.33

112026.67

125033.33

124900.00

108870.00

114083.33

137603.33

135416.67

113920.00

\section{Net income (Rs ha ${ }^{-1}$ )}

62923.33

61677.53

52524.80

32012.27

68475.00

73059.20

64376.47

39903.93

68101.67

72502.53

63759.80

39120.60

70143.33

85057.53

74261.47

44155.60
Benefit-Cost Ratio

1.43

1.17

0.86

0.46

1.56

1.39

1.05

0.57

1.55

1.38

1.04

0.56

1.60

1.62

1.21

0.63 
Fig.1 Effect of INM on growth and yield of Okra

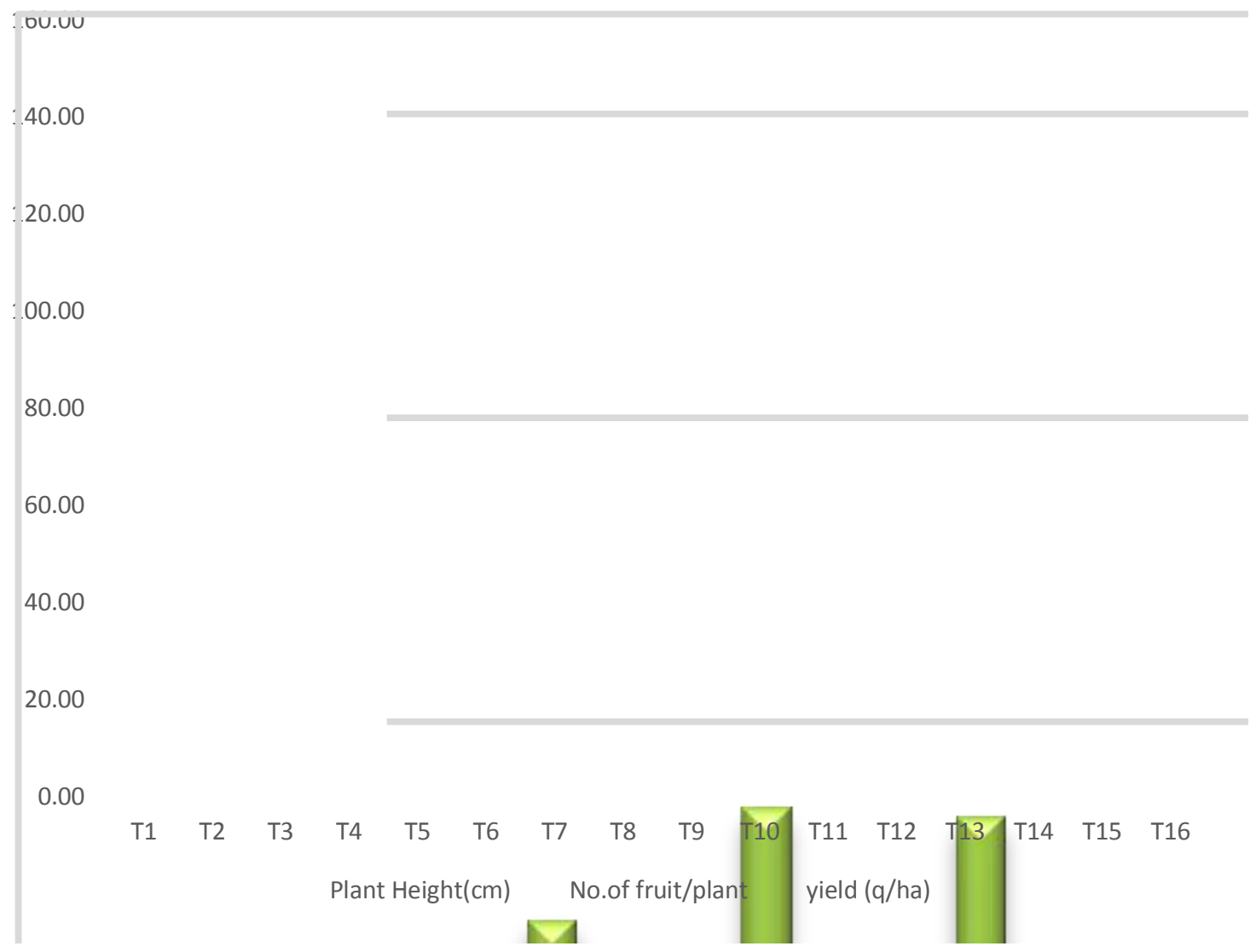

Fig.2 Effect of INM on benefit: cost ratio

\section{BENEFIT-COST RATIO}

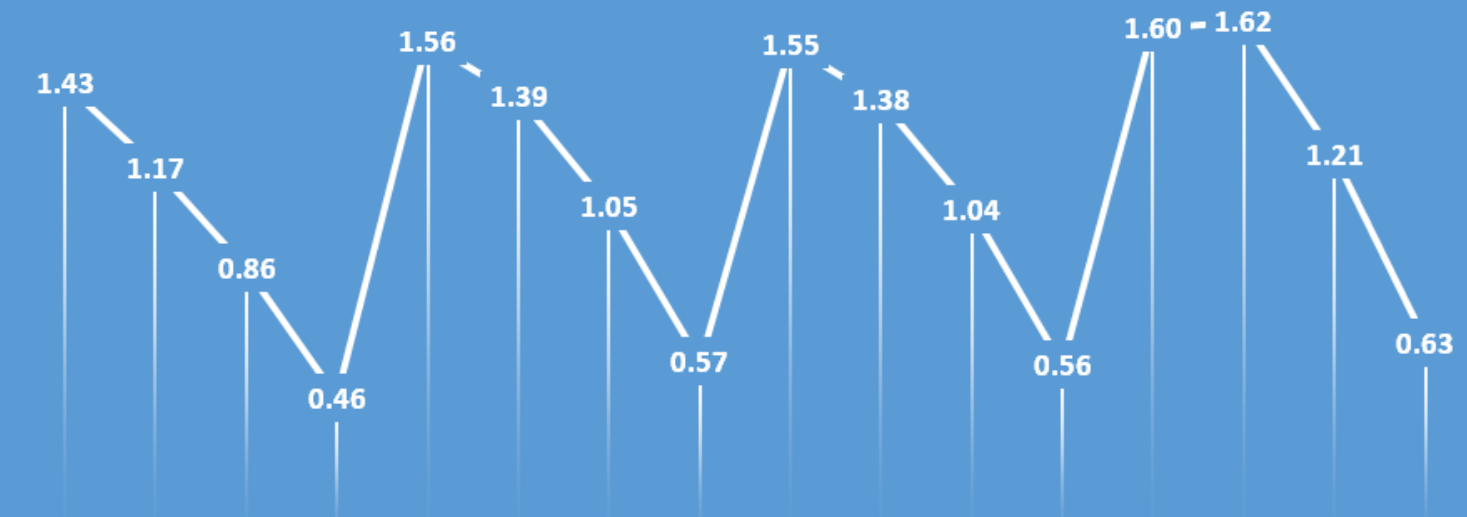


The highest fruit length $(15.47 \mathrm{~cm})$, fruit diameter $(16.20 \mathrm{~mm})$, average fruit weight $(14.10 \mathrm{~g})$, number of fruit per plant (24.83), fruit yield per plant (349.48 g) and fruit yield per hectare $(137.60$ q) was recorded in treatment $\mathrm{T}_{14}(75 \% \mathrm{RDN}$ through chemical fertilizer $+25 \%$ RDN through vermicompost + Azotobacter + PSB). The progressive improvement in the parameters due to the treatment $\mathrm{T}_{14}$ maybe due to the fact that the integrated use of chemical fertilizer, biofertilizers and vermicompost might have resulted in better improvement, establishment and availability and uptake of nutrients that have resulted in better vegetative growth, more count of bacterial and fungal population and promoted the plant metabolic activity and resulted better vegetative growth, synthesis of carbohydrate and ultimately the fruit size. The significant increase in yield in okra with the integration of nutrient may be due to vigorous vegetative growth and increased chlorophyll content, which together might have accelerated the photosynthetic rate and thereby increased the supply of carbohydrate to plants. It is well established fact that the supplementation of organic manures and biofertilizers improve soil physical, chemical and biological properties. Organic sources of nutrients might have provided the base for better absorption of nutrients which accelerated the rate of photosynthesis and ultimately the yield of fruits. The number of fruits per plant and average fruit weight had the direct and positive contributory factors to yield per plant in okra due to their direct effects. The results of the present study are in the close conformity with the findings of Singh et al., (2010), Naik et al., (2012), Bhushan et al., (2013).

\section{Quality parameters}

It was notice that the various quality parameters i.e. TSS, ascorbic acid and crude protein content of the fruit varied significantly due to various integrated nutrient management options (Table 2). The highest TSS, ascorbic acid and crude protein content $\left(2.42^{\circ}\right.$ Brix, $\quad 15.37 \mathrm{mg} / 100 \mathrm{~g}, \quad 16.63 \%$ respectively), was analysed under the treatment receiving $75 \%$ RDN through chemical fertilizer $+25 \%$ RDN through vermicompost + Azotobacter + PSB $\left(\mathrm{T}_{14}\right)$. However, the lowest values were found under Recommended Dose of Fertilizers $\left(\mathrm{T}_{1}\right)$. The progressive increase in the parameters may be due to the fact that the vermicompost being a major contributor of micronutrients to soil and plant growth promoters like gibberellins, cytokines and auxins, might have improved the physical (like bulk density, porosity, water holding capacity, soil structure), chemical (nutrient status, soil $\mathrm{pH}$ ) and biological properties (Azotobacter and PSB, fungi, actinomycetes, earthworms activities) of soil by enriching the certain metabolites and vitamins that had provided favourable environment for better growth and development of plant which ultimately increased the synthesis and accumulation into the fruit. The beneficial effects of bacterial inoculation on increased protein content and elemental nutrition also might be due to the increased availability of nitrogen to the growing tissue and organs supplied by nitrogen fixing Azotobacter. The inorganic fertilization treatment produced the lowest crude protein content, when compared with the other treatments. The findings get full support with the findings of Sammera et al., (2005), Yogita and Ram (2012) and Yadav et al., (2016).

\section{Economics of production}

The various INM treatments exhibited noticeable influence on the economics of okra cultivation (Table 3 and Fig. 2). It is obvious from the table that the application of $75 \%$ RDN through chemical fertilizer $+25 \% \mathrm{RDN}$ through vermicompost + Azotobacter + PSB 
$\left(\mathrm{T}_{14}\right)$ resulted in higher gross returns of Rs. $137603.33 \mathrm{ha}^{-1}$, net returns Rs. 85057.53ha ${ }^{-1}$ and benefit: cost ratio (1.62). The higher gross return under the treatment mentioned is obviously due to higher total green fruit yield of okra variety VNR Super green. Similar findings through conjunctive use of organic manures, bio-fertilizers and chemical fertilizers have also been made by Ferdous et al., (2017), Jat et al., (2017) and Bharthy et al., (2017).

\section{References}

AOAC (2001) Association of Official Analytical Chemists, Washington DC, USA

Bharthy RB, Sankaran M and Subrmani T (2017). Effect of integrated nutrient management on nutrient uptake and yield of okra [Abelmoschus esculentus (L.) Moench] under islands conditions. Journal of Crop Improvement, 8(1):2430

Bhushan A, Bhat KL and Sharma JP (2013). Effect of Azotobacter and inorganic fertilizers on fruit and seed yield of okra cv. Hisar Unnat. Agriculture Science Digest, 33 (2): 135-138

Chattopadhyay A, Dutta S and Chatterjee S (2011). Seed yield and quality of okra as influenced by sowing dates. African Journal of Biotechnology 10(28): 54615467.

Chauhan, D V S (1972). Vegetable Production in India, 3rd Ed., Ram Prasad and Sons, Agra

Dange RG, Naik DM and Prabu T (2002). Effect of organic and inorganic fertilizers on growth, yield and quality of chilli (Capsicum annum L.). South Indian Horticulture, 50:578-583.

Das AK, Prasad B and Singh R (2014). Response of chemical fertilizer and vermicompost on okra (Abelmoschus esculentus) cv. Prabhani Kranti. The
Asian Journal of Horticulture, 9(2): 372-376.

Dick WA and Greorich EG (2009). Developing and maintaining soil organic matter levels. in managing soil quality; challenges in mrdenscjoing. $\mathrm{P}$. Elmbolt. S and Christensem BT (EDS), CA BInternational, Wallingford, UK pp 103-120

Ferdous Z, Anwar M, Uddin N, Ullah H and Hossain A (2017). Yield performance of okra (Abelmoschus esculentus) through integrated nutrient management. International Journal of Biosciences, 10 (1):294-301.

Jat MK, Tikko A, Yadav PK, Yadav SS and Yadav PVS (2017). Effect of integrated nutrient management on yield, soil fertility and economics in Abelmoschus esculentus - Allium cepa cropping system in semi-arid zone of Haryana. Journal of Pharmacognosy and Phytochemistry, 6(4): 1142-1145.

Lambert DH, Baker DE and Cole H (1979.) The role of mycorrhizae in interactions of phosphorus with Zinc, Copper and other elements. Soil Society American Journal, 43: 976-980

Motsara MR and Roy RY (2008). Guide to laboratory establishment for plant nutrient analysis, food and agriculture organization of the United Nations Rome

Naik HM, Rao GB and Srihari G (2012). Influence of integrated Nitrogen Management Practices on Growth and yield of okra (Abelmoschus esculentus L.) cv. Arka Anamika. Journal Research ANGRAU, 40(4): 11-13

Panse VG and Sukhatme PV (1985). Statistical Methods for Agricultural Workers. Indian Council of Agricultural Research, New Delhi, India, pp 152-61

Sameera DL, Shankaraiah V and Srihari D (2005). Effect of packaging and storage on organic manures grown okra 
(Abelmoschus esculentus (L.) Moench). Journal of Research ANGRAU, 33:3035

Sharma DP, Prajapati J and Tiwari A (2014). Effect of NPK, vermicompost and vermiwash on growth and yield of Okra. International Journal of Basic and Applied Agricultural Research, 12(1):5-8.

Sharma GR and Choudhary MR (2011). Effect of integrated nutrient management on growth, yield and quality of okra [Abelmoschus esculentus (L.) Moench]. M.Sc. (Ag.) thesis submitted to Swami Keshwan and Rajasthan Agricultural University, Bikaner.

Singh JK, Bahadur A, Singh NK and Singh TB (2010). Effect of using varying level of NPK and biofertilizers on vegetative growth and yield of okra [Abelmoschus esculentus (L.) Moench]. Vegetable Science, 37 (1): 100-101
Singh SK, Kumar S, Yadav YC and Kumar A (2012). Effect of NPK levels on growth, yield and quality of okra cv. Arka Anamika. Horticulture flora Research Spectrum, 1 (2): 190-192.

Vishnyakov GN and Kornysheva SV (2005). Provision of measurement uniformity in refractometry of solids, liquids and gases. Measurement Technique, 48:1099102

Yadav SC, Yadav G, Gupta G, Prasad VM and Bairwa M (2016). Effect of integrated nutrient management on quality and economics of okra (Abelmoschus esculentus (L) Moench). International Journal of Farm Sciences, 6 (3):233-237.

Yogita and ram BR (2012). Interaction effect of chemical and bio-fertilizers on onion, Horticulture Floriculture Research. Spectrum, 1(4):360-370

\section{How to cite this article:}

Bipul Kumar Singh, R.B. Verma, V.K. Singh, Mahendra Singh and Deepak Maurya. 2018. Effect of Integrated Nutrient Management on Growth, Yield And quality of Okra (Abelmoschus esculentus (L.) Moench). Int.J.Curr.Microbiol.App.Sci. 7(10): 1033-1041. doi: https://doi.org/10.20546/ijcmas.2018.710.115 